\title{
The Relationship between Innovation Capabilities and Efficiency of Foreign Invested Enterprises in Vietnam
}

\author{
Le Thi Thu Ha*, Pham Thuy Linh, Ho Thi Thu Quynh, Tran Thi Kim Chi \\ Foreign Trade University, 91 Chua Lang, Dong Da, Hanoi, Vietnam
}

Received 24 March 2016

Revised 15 May 2016; Accepted 23 June 2016

\begin{abstract}
Similar to the previous researches, this study confirms the positive relationship between innovation capabilities and efficiency of a company by measuring and evaluating the experimental data from 52 foreign invested enterprises in Vietnam (FIEs). The study provides insight into different aspects related innovation of FIEs such as: types of innovation, frequency of innovation implementation, methods of innovation investment. Results of the analysis of primary data by the linear regression method show the relatively small differences in the impacts of 7 groups of capabilities on efficiency of the company, even though the development capabilities still have made greatest influence with the coefficient of 0.453 . The findings of this research once again stress that innovation and innovation capabilities of the company is the decisive element of primary efficiency.
\end{abstract}

Keywords: Foreign invested enterprises, Innovation, Innovation Capabilities.

\section{Introduction}

In such an internationalized and fiercely competitive business environment, innovation has become the key to economic and societal development of every nation, as well as a strategic tool to ensure enterprises' survival and sustainable progress in the market $[1-4]$. Innovation-driven growth is no longer a privilege of developed countries, developing countries also have created policies to promote innovation capacity, and many of which have gained remarkable achievements in improving both innovation inputs and outputs [5, 6]. Both theoretical and empirical evidence show that the

\footnotetext{
*Corresponding author. Tel.: 84-912211178

Email: ha.le@ftu.edu.vn
}

countries would go through different developmental stages, depending on the ability to identify and implement their innovations.

From the perspective of enterprises, several researches have demonstrated empirical evidence of the positive relationship between innovation and new products, services and production process [7 - 14]. According to David (1997), value creation is the requirement for any firms in market economy and innovation is the tool to create value for them. Because customers tend to be attracted by new product and service selections, when firms discontinue attempts to innovate, they may lose a certain number of customers [15]. Thus, the implementation of innovation is not only the need but also a priority of any managerial strategies. 
In Vietnam, innovation has recently become the topic of concerns and attention. Over the past 7 years, the Global Innovation Index of Vietnam has gone through an upward trend and ranks third in the region, after Singapore and Malaysia in 2015[16]. However, there are still many shortcomings. The official investment for science, technology and innovation development (STI), which makes up from $65 \%$ to $70 \%$ of total investment, only accounts for $2 \%$ of public budget, equivalent to $0.5 \%$ GDP (about one billion USD) [17]. Most Vietnamese enterprises do not invest in $R \& D$ activities, only $20-30 \%$ of them have innovation activities [17]. Instead of investing in technology and knowledge, they mainly rely on the advantages of cheap labor and raw materials exploitation. In contrast, FIEs in Vietnam, which seem to be more productive and agile in implementing innovation, have significantly contributed to the development of the national economy. In addition to technology spillover effect, Vietnamese enterprises also learn from FIEs about how to enhance innovation capabilities.

This research focuses on the exploration of different innovation types developed by FIEs and how innovation capabilities can affect their business performance.

\section{Literature review}

Innovation capabilities are defined as the ability to create or seek for new ideas, opportunities, knowledge or resources from endogenous potentials and external environment. Thereby, firms can exploit and apply them to production process and operation system to create added value and improve competitiveness [18-22].

The evaluation criteria of innovation capabilities are diverse and based on different perspectives. Betrand (2009)assessed them based on the amount of R\&D investment [23]. Nassimbeni (2001) separated innovation capabilities in products with production process
[24]. Forsman (2011) launched the set of 7 evaluation criteria that covers many aspects of business, including: (1) Capabilities for knowledge exploitation, (2) Entrepreneurial capabilities, (3) Risk management capabilities, (4) Networking capabilities, (5) Development capabilities, (6) Change management capabilities, (7) Market and customer knowledge [25]. These criteria are also reflected through 10 dimensions of i2Metrix paradigm [26]. In particular, capabilities for knowledge exploitation and entrepreneurial capabilities are considered to be the dynamic capabilities of firms [27] and help enhance position of firms through acquiring and applying external knowledge and opportunities to operation. When conducting innovation in a foreign market, beside new opportunities, FIEs also face various risks caused by internal and external factors. It explains why risk management and networking capabilities play significant roles in the operation, adaptation and long-term strategic interests [28-30]. Innovation is also reflected through the ability to grasp market trends, customer preferences and to differentiate products or services to improve the growth rate and market share [31-35].

Firm performance has drawn great attention in management studies. Firm performance is defined as the success of firms in term of financial activities, operation, and ability to achieve the expected business outcomes [36 - 38]. Studying about business performance plays an important role in understanding the impact of innovation capabilities since it is viewed as a measure of effectiveness of any managerial strategies [36].

There are various ways to measure business performance of different kinds of enterprises: finance companies, exporting firms, small and medium-sized enterprises and multinational enterprises [39 - 43]. In this research, financial, non-financial and subjective factors are used to measure firm performance. Because of their rigidity, financial factors cannot reflect the differences among industries 
and abstract capabilities. Non-financial and subjective factors have advantages in demonstrating endogenous capabilities and the relationships between subsidiaries and parent companies [44, 45].Financial factors include revenue, cash flow, ROI, ROE, etc. Nonfinancial factors are comprised of customer acquisition, customer loyalty, employee loyalty, etc. Subjective factors are managers' ability to acquire knowledge/skills, cooperation between managers and departments, long-term vision, etc.

The relationship between innovation and firm performance has been mentioned in several quantitative and qualitative researches. Most of them conclude that innovation has a positive impact on firm performance through improving productivity, reducing lead time, improving product quality, etc.[46 - 49]. Regarding the relationship between innovation capabilities and firm performance, GarciaMorales et al. (2007), Rosenbusch (2009),Tsai et al (2010), Forsman (2011), Dadfar et al. (2013),and Saunila (2014)have examined and concluded that it is significant and positive [22, 25, 50 - 53]. The enterprises having outstanding innovation capabilities reflected through technology forms, innovation in management or product development are proved to have satisfactorily high business results. In Vietnam, the relationship between innovation capabilities and firm performance, however, has not drawn significantly enough concerns in terms of theory and practice. Hardly any research is found to discuss which types of innovation and innovation capabilities that Vietnamese enterprises and FIEs in Vietnam possess as well as their effects on firm performance.

\section{Methodology}

Both qualitative and quantitative methods are used to examine the relationship between innovation capabilities and firm performance. The model used in the research is the combination of the 7-indicator model by Forsman (2011), i2Metrix paradigm (Vuong et al, 2014) and the theoretical model of Chow (2006) $[25,54,55]$. The independent variable is the innovation capabilities, the dependent variable is firm performance, and both of them are influenced by the control variables (size of firms, industries that firms are working in). All the relevant data related to these variables are then analyzed using SPSS.

The independent variable is measured by 7 dimensions, including: Capabilities for knowledge exploitation, Entrepreneurial capabilities, Risk management capabilities, Networking capabilities, Development capabilities, Change management capabilities, Market and customer knowledge. The magnitude of each dimension is then specified by the relevant criteria related to innovation capabilities of enterprises.

Concerning the capabilities of knowledge exploitation, Bapuji (2011) has confirmed the external knowledge support for the internal knowledge of a firm, and the combination of these two strengthens the competitive advantages of the firm and helps boost the business efficiency[56]. Entrepreneurship is considered to be one of the most important capabilities since it is directly linked to business performance $[57,58]$. If a firm lacks this kind of capabilities, it cannot create any benefit from the application of external knowledge. Networking, according to Powell (2001), presents both new opportunities and constraints for its actors[59]. The relationships in a network are seen as the pipes containing the flow of many resources, both tangible and intangible such as finance, skills and information. For development capabilities, Erik Strøjer Madsen and Valdemar Smith Com (2008), have demonstrated that the ability to differentiate product/service of a firm is an independent variable that is statistically significant and has positive impact on the business efficiency[60]. Other studies also suggest that product differentiation and firm performance have a positive relationship [61 63]. Change management capabilities in business process, workflow and customer management have been proved to have a positive impact on many dimensions of 
business operation, such as financial performance, resources, customer and market efficiency [30]. Finally, the ability to understand the market and customers basically can increase creativity[33, 35], because it encourages firms to find the potential demand of customers [31].

The dependent variable-firm performance is evaluated by financial factors (ROE, ROI and net income), non-financial factors (labor productivity, defective products, new products, human resource training, market share growth and customer satisfaction) and subjective factors of managers (ability to acquire new knowledge/skills, long-term perspective on the business, cooperation with other departments within the organization and subjective evaluation of the firm's growth rate when compared to others).

\section{The financial perspective}

The financial perspective retains the shortterm approach of measuring ROE, ROI and net income, mainly because these measurements indicate the company's financial success from a shareholder's point of view. The financial perspective evaluates whether the company's strategies are translating into bottom-line improvements of the company. Financial measures tend to be historical, and do not reveal the present situation of the business environment and the prospects of the future performance. However, financial measures are still important as there is no guarantee that improved operating performance will indeed lead to financial success [64]. The financial factors such as ROE and ROI to measure the profitability of an organization are significant to its success, therefore cannot be dismissed. According to Kaplan \& Norton (1992), operational improvements that do not lead to financial success indicate the implementation of the strategy of an organization needs to be revisited[64]. However, trying to capture the success strategy using the traditional financial indicators requires the selection of financial measures that will most effective suited by the product life cycle stage. There are three possible stages described by Kaplan and Norton (1996) [43], that is rapid growth, sustain, and harvest. For the growth stage, companies will probably use measures such as increased sales volumes, acquisition of new customers, and growth in revenues that can evaluate the growth and development of the company. In the sustain stage financial measures will be return on investment (ROI) and the return on equity (ROE), measures on this stage are purposely directed to evaluate the effectiveness of the organization. Finally, the harvest stage, measures are payback periods and revenue volume aimed to reap the rewards of the strategy that will potentially be based on different cash flow analysis that attempt to evaluate the company's success in harvesting profits from maturing products or services.

\section{The non-financial perspective}

The non-financial perspective includes the customer and growth perspective. The customer perspective includes not only market share and new customer acquisition but also measures related to the value propositions that the company will deliver to its customers, such as customer intimacy, operational excellence or product leadership [65]. The aim of the customer perspective is to ascertain the needs of the customers, and then devise appropriate the value the company wants to apply to the enduser that will potentially satisfy their needs taking into account the measure of quality and perceived value of the products or services that are supplied to the customer. According to Kaplan and Norton (1992), customers are primarily concerned with time, quality, performance and service, and costs [64]. For a company to attain its customer satisfaction and retention ought to deliver on time, offer innovative products/services and technological excellence that will render the company's offering at a satisfactory cost, because if customers are not satisfied, they will seek products and services elsewhere. Customer measures are considered leading indicators of future performance. On the other hand, the learning and growth perspective identifies 
the capabilities required to deal with the competitive envir,onment so as to create longterm growth and continuous improvement [65]. The purpose of the innovation and learning perspective is to determine the ability of the company to continually improve and innovate. This is the foundation of any strategy and centers on the human and intangible assets of the company. As discussed earlier, intangible assets are increasingly important in today's globalized economy as business success lies on it. Thus, the focus is mainly on the internal skills and capabilities that are required to support the value creation, which includes the areas of individual and corporate selfimprovement and technological support and tools. This perspective tries to define the human and developmental requirements of the company that will enable ambitious objectives in the other three perspectives to be achieved. To increase shareholder value a firm must constantly able to innovate, learn, and improve which will result in firm growth. Theoretically, through increased improvement, businesses are able to improve their internal processes, leading to greater customer satisfaction, corporate growth, and increased profits [66]. The possible measures in this perspective are illness rates, employee turnover, education, and development.

\section{The subjective judgment perspective}

The term "subjective judgment" represents the nonfinancial measures that are derived from the subjective judgment of managers. Since performance evaluations serve multiple goals, subjective evaluation plays a significant role in term of incentives and performance feedback [67]. Moreover, many studies prefer the subject measurements since it allows comparison among firms and contexts, such as time horizons, types of industry, cultures and economic conditions [68]. Managers of all levels have certain impacts on employees and strategies; hence, their judgment can affect business navigation and innovation. According to Chow (2006), while subjective performance evaluations are less precise than financial ones, they are focused on the operation factors that managers can control[55]. Besides, the following factors: education background of interviewees, the type, and frequency of innovation, the amount of investment for innovation serve as variables of descriptive statistics.

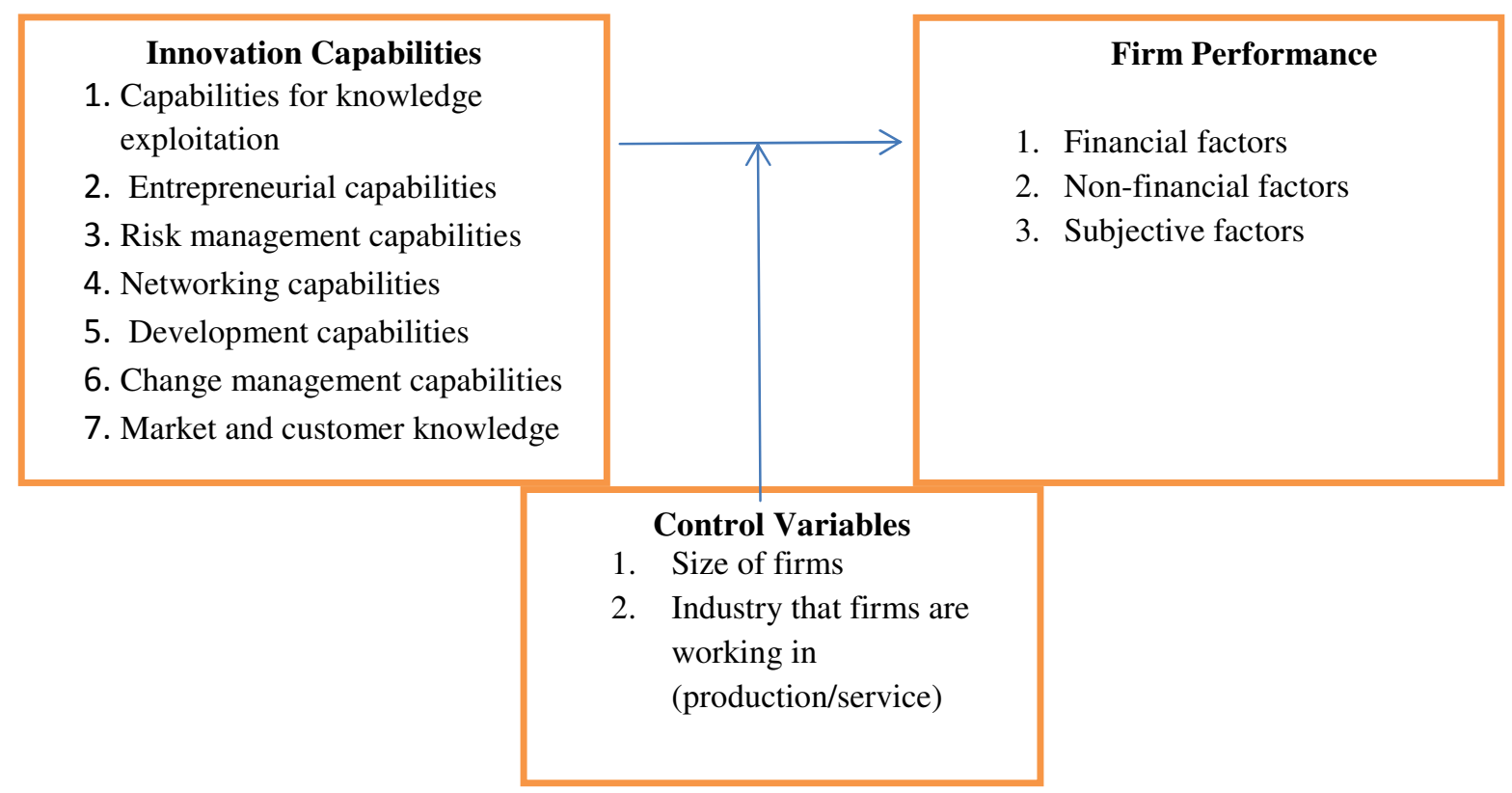




\section{Sample}

The survey was conducted with a questionnaire using Likert scale. It consists of 4 sections: personal information of interviewees (6 questions), enterprise information (8 questions), innovation capabilities (20 small questions categorized in 7 big questions) and firm performance (12 small questions grouped into 2 big questions). The survey was conducted via e-mail, postal mail and direct interview.We have asked the entrepreneurs/key managers of the firms to rate positions of these in their firms in a 5 point Likert scale. Due to firms' hesitation to share their financial information in the absolute form as well as complex accounting practices in Vietnam, we consider perception-based growth measures to be appropriate in this case.

The sample is built based on area sampling. The enterprises participating in the survey are foreign invested enterprises in Red River Delta, North Central Coast, Southeast Region of Vietnam.Research team received 52 responses. The majority of survey respondents were managers $(90,5 \%)$ with $58.3 \%$ is the CEO / Director / Branch Manager. Most enterprises were medium $(46.1 \%)$ or small $(38.5 \%)$ with $63.5 \%$ in the manufacturing sector and $36.5 \%$ in the services sector. Nearly all of these enterprises are implementing innovation with different types $(15.4 \%$ introducing new products/services, $26.9 \%$ improving current products, $53.8 \%$ improving workflow / management / sales / marketing), 50\% of them conduct innovation periodically, $57.7 \%$ through $\mathrm{R} \& \mathrm{D}$ with the investment of $1-3 \%$ of revenue.

\section{Analysis}

The data collected from the survey have been processed by SPSS to examine the relationship between innovation capabilities and firm performance of FIEs in Vietnam. The 3-step examination was conducted as follows:

Step 1: Checking the reliability of the responses from the questionnaire

Step 2: Conducting Exploratory Factor Analysis (EFA).
Step 3: Conducting OLS Regression.

Step 1: Checking the reliability of the responses from the questionnaire through Cronbach Alpha.

In accordance with the suggestion of Werts, Linn and Jöreskog (1974), research team checked the reliability of the responses from the survey using Cronbach alpha[69]. This step is carried out first to remove garbage items, which helps to prevent artificial factors when analyzing EFA [70]. Nunnally and Bernstein (1994)showed that composite reliability or Cronbach alphashould be at least 0.50 for any dimension of the conceptual model and in this research, the level of 0.70 is applied as the minimum acceptance criterion[71]. Research team has checked convergent validity of the indicators by examining the 'average variance extracted (AVE)'. Götz, Liehr-Gobbers and Krafft (2009)reported that an AVE value of at least 0.5 indicates sufficient convergent validity, which means a latent variable is able to explain more than half of the variance of its indicators on an average, and this figure is maintained this standard in this paper[72].

The result identifies some responses to 4 questions which are not correlated with others in the questionnaire and are removed before analyzing the next steps, including question 1.3 (belonging to Capabilities for knowledge exploitation), question 2.1 (belonging to entrepreneurial Capabilities ), question 5.3 (belonging to development capabilities), and ROI, Net Profit, Labor productivity and Customer satisfaction (belonging to variable business activities).

\section{Step 2: Conducting Exploratory Factor Analysis (EFA)}

In this research, Exploratory Factor Analysis (EFA), a multi-step process is used to determine the factors representing the dependent variable and independent variables[73]. This analysis attempts to bring inter-correlated variables together under more general, underlying variables. More specifically, the goal of EFA is to reduce "the 
dimensionality of the original space and to give an interpretation to the new space, spanned by a reduced number of new dimensions which are supposed to underlie the old ones" [74], or to explain the variance in the observed variables in terms of underlying latent factors" [75]. Thus, EFA offers not only the possibility of gaining a clear view of the data, but also the possibility of using the output in subsequent analysis [74, 76].

On the other hand, as Rietveld \& Van Hout (1993)states "the number of positive eigenvalues determines the number of dimensions needed to represent a set of scores without any loss of information"[74]. Hence, the number of positive eigenvalues determines the number of factors to be extracted. The construction of the factor itself is then calculated via a transformation matrix that is determined by the eigenvectors of the eigenvalues. After constructing the factors, it is possible to determine the factor loadings simply by calculating the correlations between the original variables and the newly obtained factors. Hair et.al. (1998, pg. 111) recommends the following guidelines for practical significance as below[77]:

- Factor loading >0.3: Accepted minimal

- Factor loading > 0.4: More Important significance

- Factor loading > 0.5: Practical Significance

Moreover, Oblimin, an oblique rotation, is employed and illustrates the results including a pattern matrix, structure matrix, and a component correlation matrix. In Extraction Sums of Squared Loadings, Percentage of variance more than $40 \%$ is applied as the minimum acceptance criterion, which answer the question how many percentages the new factor can explain to represented variable.

In extraction process, Research team used Principal Components analysis and fixed number of factor at one factor only for the dependent variable (Firm performance) and each dimension of innovation capabilities, before moving to regression, are named as below:

\begin{tabular}{|c|c|c|c|c|}
\hline & Independent variables & & Dependent variable & \\
\hline Hypothesis & Capabilities for knowledge & $E \wedge C 12$ & 1. ROE & \\
\hline H1 & exploitation & FACI_Z & 2. Defective & \\
\hline $\begin{array}{l}\text { Hypothesis } \\
\text { H2 }\end{array}$ & Entrepreneurial capabilities & FAC1_3 & $\begin{array}{l}\text { 3. New products } \\
\text { introduction }\end{array}$ & \\
\hline $\begin{array}{l}\text { Hypothesis } \\
\text { H3 }\end{array}$ & Risk management capabilities & FAC1_4 & $\begin{array}{l}\text { 4. Human resources } \\
\text { training }\end{array}$ & \\
\hline $\begin{array}{l}\text { Hypothesis } \\
\text { H4 }\end{array}$ & Networking capabilities & FAC1_5 & $\begin{array}{l}\text { 5. Human resources } \\
\text { training }\end{array}$ & \\
\hline $\begin{array}{l}\text { Hypothesis } \\
\text { H5 }\end{array}$ & Development capabilities & FAC1_6 & $\begin{array}{l}\text { 6. Human resources } \\
\text { training acquire new }\end{array}$ & FAC1_1 \\
\hline $\begin{array}{l}\text { Hypothesis } \\
\text { H6 }\end{array}$ & Change management capabilities & FAC1_7 & $\begin{array}{l}\text { skills/knowledge } \\
\text { 7. Managers' long-term }\end{array}$ & \\
\hline $\begin{array}{l}\text { Hypothesis } \\
\text { H7 }\end{array}$ & Market and customer knowledge & FAC1_8 & $\begin{array}{l}\text { perspective } \\
\text { 8. Managers' }\end{array}$ & \\
\hline $\begin{array}{l}\text { Hypothesis } \\
\text { H0 }\end{array}$ & Innovation capabilities & FAC1_9 & $\begin{array}{l}\text { cooperation with other } \\
\text { departments within the } \\
\text { organization }\end{array}$ & \\
\hline
\end{tabular}

In SPSS, a convenient option is offered to check whether the sample is big enough: the Kaiser-Meyer-Olkin measure of sampling adequacy (KMO-test). The sample is adequate if the value of $\mathrm{KMO}$ is greater than 0.5 and less than or equal one $(0.5 \leq \mathrm{KMO} \leq 1)$. Furthermore, SPSS can calculate an anti-image matrix of covariance and correlations. All 
elements on the diagonal of this matrix should be greater than 0.5 if the sample is adequate [76]. In SPSS the inter-correlation can be checked by using Bartlett's test which "tests the null hypothesis that the original correlation matrix is an identity matrix" [76]. This test has to be significant with Significance $<0.05$, this means that the observed variables are correlated with each other in general. Multicollinearity, then, can be detected via the determinant of the correlation matrix: if the determinant is greater than 0.00001 , then there is no multicollinearity [76].

\section{Step 3: Regression}

This research uses the Ordinary Least Squares (OLS) regression through IBM SPSS. 2.0 Program. OLS regression in its various forms (correlation, multiple regression, ANOVA), is the most common linear model analysis in the social sciences [78]. Habing (2003)states that "a sample should have at least 50 observation."[75]. OLS illustrates the relationship between a dependent variable and a collection of independent variables. In addition, the regression coefficients are interpreted as the change in the expected value of the dependent variable associated with a one-unit increase in an independent variable, with the other independent variables held constant. From extracted factors EFA Analysis, Research team conducted regression models for eight hypotheses to find out the relationship between innovation capabilities and firm performance, 7 dimensions measuring innovation capabilities and firm performance.

Besides that, Pearson's correlation coefficient is used to find out the correlation between independent variables and dependent variable. In a sample it is denoted by $r(-1 \leq \mathrm{r} \leq$ 1). Furthermore, positive values denote positive linear correlation while negative values denote negative linear correlation. A value of 0 denotes no linear correlation. The closer the value is to 1 or -1 , the stronger the linear correlation is.

The Durbin-Watsontests the null hypothesis that the residuals from an OLS regression. It ranges from 0 to 4 . A value near 2 indicates non-autocorrelation; a value towards 0 indicates positive autocorrelation; a value toward 4 indicates negative autocorrelation.

In theory, VIF (Variance Inflation Factor) over 10 is a sign of multicollinearity. However, this factor in the research (small size) is lower than 2.0 ensuring that the model, which is tested, does not have multicollinearity.

\section{Results and discussion}

Descriptive results from questionaire

\begin{tabular}{|c|c|c|c|c|c|}
\hline & \multicolumn{2}{|c|}{ Descriptive Statistics } & \multirow[b]{2}{*}{ Maximum } & \multirow[b]{2}{*}{ Mean } & \multirow[b]{2}{*}{$\begin{array}{l}\text { Std. } \\
\text { Deviation }\end{array}$} \\
\hline & $\mathrm{N}$ & Minimum & & & \\
\hline \multicolumn{6}{|c|}{ Capabilities for knowledge exploitation } \\
\hline Recognize this knowledge & 52 & 1 & 5 & 4.00 & .863 \\
\hline Internalize this knowledge & 52 & 2 & 5 & 3.73 & .843 \\
\hline \multicolumn{6}{|l|}{ Entrepreneurial capabilities } \\
\hline Seize these opportunities & 52 & 1 & 5 & 3.60 & .995 \\
\hline Exploit these opportunities & 52 & 1 & 5 & 3.38 & .820 \\
\hline \multicolumn{6}{|l|}{ Risk management capabilities } \\
\hline Capabilities of risk assessment & 52 & 1 & 5 & 3.56 & .826 \\
\hline Willingness to risk taking & 52 & 1 & 5 & 3.44 & .998 \\
\hline Abilities for risk taking & 52 & 1 & 5 & 3.54 & .896 \\
\hline \multicolumn{6}{|l|}{ Networking capabilities } \\
\hline Networking orientation & 52 & 1 & 5 & 3.92 & .837 \\
\hline Collaborative relationship creation & 52 & 3 & 5 & 4.02 & .754 \\
\hline
\end{tabular}




\begin{tabular}{llllll}
\hline $\begin{array}{l}\text { Networks exploitation } \\
\text { Development capabilities }\end{array}$ & 52 & 1 & 5 & 4.00 & .886 \\
$\begin{array}{l}\text { Generate innovations which differ from } \\
\text { competitors' offerings }\end{array}$ & 52 & 1 & 5 & 3.35 & .905 \\
$\begin{array}{l}\text { Improve existing goods and services } \\
\text { Change management capabilities }\end{array}$ & 52 & 1 & 5 & 3.48 & .960 \\
$\begin{array}{l}\text { Quickly implement changes } \\
\text { Market and customer knowledge }\end{array}$ & 52 & 2 & 5 & 3.69 & .805 \\
Acquire new customers & 52 & 2 & 5 & 3.73 & .689 \\
Expand to new markets & 52 & 2 & 5 & 3.67 & .760 \\
Increase sales to existing customers & 52 & 2 & 5 & 3.69 & .755 \\
Firm Performance & 52 & 3 & 5 & 4.10 & .634 \\
Return on equityROE & 52 & 2 & 5 & 3.79 & .936 \\
$\begin{array}{l}\text { Defective } \\
\text { New products introduction }\end{array}$ & 52 & 2 & 5 & 3.98 & 1.000 \\
Human resources training & 52 & 2 & 5 & 4.12 & .832 \\
Market share growth & 52 & 2 & 5 & 3.88 & .943 \\
Managers' ability to effectively acquire & 52 & 2 & 5 & 4.00 & .657 \\
new skills/knowledge & 52 & 2 & 5 & 4.37 & .595 \\
Managers' long-term perspective & 52 & 2 & 5 & 4.21 & .871 \\
Managers' cooperation with other & 52 & & & & \\
departments within the organization & & & 5 & \\
\hline
\end{tabular}

In general, the self-evaluation of innovation capabilities from surveyed FIEs is quite high with the total average scores of each reported capability ranging from 3.35 to 4.02 . Networking Capabilities and Knowledge exploitation Capabilities are two aspects that FIEs have well recognized andeffectively developed.

The impacts of innovation capabilities on firm performance

\begin{tabular}{llll}
\hline Innovation capabilities & Coeffi. & Sig. & R Square \\
\hline Capabilities for knowledge exploitation -> Firm Performance & .389 & $.005^{* * *}$ & .212 \\
Entrepreneurial capabilities -> Firm Performance & .433 & $.002^{* * *}$ & .234 \\
Risk management capabilities -> Firm Performance & .332 & $.019^{* *}$ & .169 \\
Networking capabilities -> Firm Performance & .308 & $.028^{* *}$ & .157 \\
Development capabilities -> Firm Performance & .453 & $.001^{* * *}$ & .271 \\
Change management capabilities -> Firm Performance & .426 & $.016^{* *}$ & .174 \\
Market and customer knowledge -> Firm Performance & .325 & $.024^{* *}$ & .161 \\
\hline
\end{tabular}

Results of the ordinary least square (OLS) regression analyses of the primary data reveal relatively small differences in the impacts of 7 groups of capabilities on firm performance though development capabilities still stand out to have the largest influence with the coefficient at 0.453 , networking capabilities rank last to effect firm performance with the coefficient at 0.308 . It can be observed from survey results that innovation capabilities have been outstandingly essential attributes to the success of FIEs in penetrating the new market.

\subsection{Knowledge exploitation capabilities}

The model shows that knowledge exploitation capabilities have a significant positive relationship with performance of Foreign Invested Enterprises in Vietnam. This result once again proves the role of knowledge as one of the most valuable resources for innovation as well as key drivers of business. 
According to Grant (1996) and Prusak (2001), firms in such a knowledge-based economy can sustain their competitive advantage by harnessing their own unique knowledge and building their capability to learn faster than competitors $[79,80]$. Contrary to the traditional factors of production governed by diminishing returns, every additional unit of knowledge used effectively results in a marginal increase in performance [81]. Mostly having their roots in economically developed countries, the surveyed FIEs are one step ahead of Vietnamese firms in emphasizing the importance and making a good use of internal and external knowledge. From the macroeconomic view, Vietnam's knowledge economy index (KEI) prepared by the World Bank, is 3.4 and ranking 104/145 whereas that of Singapore and Malaysia is 8.26 (23/145), 6.1 (48/145) respectively. Thus, measures should be taken by both firms and Vietnam government to recognize, internalize, and exploit knowledge for better business performance in particular and increasing the proportion of knowledge in national economy as a whole.

\subsection{Entrepreneurial capabilities}

The model shows that entrepreneurial capabilities have a significant positive relationship with performance of the surveyed firms. Over the past several years corporate entrepreneurship has been widely regarded as an effective means for revitalizing firms and enhancing performance. Conducting a research on 24 medium-sized manufacturing firms representing 14 industry segments, 39 chemical companies, and 45 Fortune 500 industrial firms representing five industry segments, Zahra and Covin (1995) concluded that entrepreneurial capability has a positive impact on long-term financial measures of company performance [82]. Furthermore, entrepreneurial capabilities, which typically leads to new product introduction or market entry, creates value through association with the discovery and exploitation of profitable business opportunities [83, 84]. Regarding FIEs in Vietnam, they have well grasped opportunities to increase product value, extend product life cycle or even introduce new products, resulting in vastly superior customer experience, firm reputation and of course revenue ans other nonfinancial rewards.

\subsection{Risk management capabilities}

The model shows that risk management capabilities have a significant positive relationship with performance of the surveyed firms. In today's hostile business environment, risk management is a stumbling block for every corporation. As mentioned by Lukianchuk (2015), risk management is a value adding technique aimed at generating additional profit to a company by giving an overview of all risky activities, constructing recovery plans and constant monitoring of day-to-day operations[85]. Examining the characteristics of firms adopting risk management, Pagach and Warr (2011)argued that risk management helps reduce the probability of financial distress and allows firms to continue their investment strategies by reducing the effect lower tail outcomes, whether earnings or cash flow, caused by unexpected events[86]. Besides, having smoother, steadier earnings and cash flow performance allows the firm to increase leverage, pursue more growth options and perhaps be more profitable. In the case of Vietnam, the asymmetric information as well as economic instability has obviously posed a great challenge to FIEs. Thus, managing risk is inevitable if FIEs want to survive and thive in whatever business area.

\subsection{Networking capabilities}

The model shows that networking capabilities have a significant positive relationship with firm performance. This result supports many other conclusions obtained from studies in many parts of the world [87] and strongly suggests the network capabilities needs to be the focus of managerial attention if the firm seeks to enhance its ability to manage in such a complicated world [88]. In fact, when penetrating into Vietnamese market, a firm 
cannot operate well without building effective internal networks (among departments within the company) and external relations (suppliers, distributors, strategic partnership units, etc.). FIEs reported in the survey are mostly extra careful and come prepared as acknowledging the important of networking in Vietnam, their self-assessment in the questionnaire shows their good networking orientation, collaborative relationship creation and networks exploitation.

\subsection{Development capabilities}

The model shows that development capabilities have the positive impact on firm performance, which is in line with the finding of Erik Strøjer Madsen and Valdemar Smith Com (2008), Bayus, Erickson and Jacobson, 2003; and Damanpour and Evan, 1984 [60 62]. Moreover, with the coefficiency of 0.453 , these capabilities are the most influencing factors to firm performance. Since the ability to innovate and introduce the new products that are differentiated with those of competitors is an advantage of the firm when entering a new market, their sales and profit would be higher than their competitors [32, 34]. Recently, Vietnamese customers have preferred foreign brands to domestic ones due to their trust and the fierce competition in the market. Low quality domestic products, counterfeit products in domestic market and strong marketing strategies of foreign companies have driven customer buying decision towards foreign brands. According to Chemical Cosmetic Association of Vietnam, from 2009 to 2011, the average revenues of cosmetics sector were US\$130-150 million, 90\% of which was said to come from foreign companies due to their widespread distribution. Thanks to this market behavior, development capabilities have not received much investment while still contributed significantly to the success of firms.

\subsection{Change management capabilities}

The model shows that relationship between change management capabilities and firm performance is positive, which is also claimed by other studies [27, 89]. Entering in a new market means the firm has to encounter with various opportunities and challenges from environmental differences, especially in such emerging and dynamic market in Vietnam, where the economic structure and policies have not been completed yet. FIEs in Vietnam have to face with complex and ever changing customer demand. The ability to deal with exogenous changes is essential for FIEs to adapt to the domestic environment, employment situation to increase productivity and efficiency.

\subsection{Market and Customer knowledge}

The model shows that market and customer knowledge has a significant positive relationship with firm performance. However, there have been controversial opinions about the effect of market and customer knowledge to firm performance. According to Bower \& Christensen(1996), customer oriented strategies sometimes create barrier to $R \& D$ and product innovation since companies may pay too much attention to current demand of customer[90]. However, this research agrees with Gatignon và Xuereb, 1997 and Han et al, 1998on the positive relationship between the market and customer knowledge and firm performance [33, 35]. These capabilities encourage companies to find out potential demand of customers, which leads to innovation [91]. Besides, these capabilities also supports for development capabilities because when firms create a new and differential product that attains enormous attention in the market, they can follow the price skimming strategy, which helps them increase profit and reduce customer retaining cost [61, 92]. One of the main purposes for FIEs to penetrate into Vietnam is to acquire new market and customer. This process requires the understanding about the domestic market and customer tastes. Innovation activities, in fact, help firms to change products, business strategies and working process to gain market share and customer loyalty. 


\section{Conclusion}

The reported statistics, relevant to results of other researches of the same topic, reveal a plausible reasoning that the relationship between innovation capabilities and firm performance can be empirically established. Data from Foreign Invested Enterprises in Vietnam suggest profound, positive and relatively equal impacts of 7 groups of innovation capabilities on firm performance in terms of financial, non-financial and subjective factors.In fact, the constantly improving innovation capabilities and investments made under a variety of innovative forms have been very important attributes to the success of FIEs in Vietnam. The paper also provides particular information about innovative activities and practices of these enterprises. FIEs doing business in eitherproduction or service industry are continuously or periodically implementinginnovation of several types, among which the most common is improving work process / management process/ sales and marketing activities (53.8\%).According to survey results, investment for innovation is mainly made through $\mathrm{R} \& \mathrm{D}$ department. This rising trend in Vietnam and the world as a whole testifies thatinnovation is no longer spontaneous act or only carried out in need of temporary business issues. Instead, innovation and innovation capabilities enhancement are now parts of synchronized strategic business plan, for which budget is not too high but at least well calculated and prepared.

The findings are subject to some limitations due to the sample size. Further studies may attempt to gather information from more enterprises in all over the country. It would be potential to extend the analysis to Vietnamese enterprises in order to identify then compare their innovation patterns with those of FIEs. The combination of theoretical assumptions, facts, and empirical data can confirm the positive relationship between innovation capabilities and firm performance. It is not merely a single phenomenon but observed in various organizations in many countries, which will certainly be strengthen in the context of the knowledge-based economy. Lots of challenges as well as opportunities lie ahead as the relationship between innovation capabilities and firm performances is more developed and exploited.

\section{References}

[1] Keller W. Absorptive Capacity: on the Creation and Acquisition of Technology in Development. Journal of Development Economics, 49 (1), 199227, 1996.

[2] Eaton, S., \& Kortum, S. International Technology Diffusion: Theory and Measurement. International Economic Review, 40 (3), 537-570, 1999

[3] Griffith, R., Redding, S., \& Van Reenen, J. Mapping the Two Faces of R\&D: Productivity Growth in a Panel of OECD Industries. Review of Economics and Statistics, 86 (4), 883-895.(2004).

[4] Fagerberg, J., Srholec, M., Verspagen, B The Role of Innovation in Development. Review of Economics and Institutions, 1 (2), Article 2. (2010).

[5] Aubert J. E., Promoting Innovation in Developing Countries: A Conceptual framework, World Bank Policy Research Working Paper 3554, (2005)

[6] The Centre for Management of IP in Health R\&D (MIHR) Developing Innovative Capacity in Developing Countries to Meet Their Health Needs, Commission on Intellectual Property Rights, Innovation and Public Health (2005).

[7] David, B. . Innovation Management Tools: A Review of Selected Methodologies. European Communities, Luxembourg, (1997).

[8] Rogers E.M., Diffusion of innovations New York: Free Press of Glencoe, 3rd Edith, (1983)

[9] Urabe K., Innovation and the Japanese management system. In K. Urabe, J. Child, \& T. Kagono (Eds.), Innovation and management international comparisons. Berlin: Walter de Gruyter, (1988).

[10] Utterback J.M, Mastering the Dynamics of Innovation. Boston, MA: Harvard Business School Press, (1994). 
[11] Afuah, A. . Innovation management: Strategies, implementation, and profits. New York: Oxford University Press, (1998).

[12] Garcia, R. \& Calantone, R. A critical look at technological innovation typology and innovativeness terminology: a literature review. Journal of Product Innovation Management, 19 (2), 110-132, (2002).

[13] McDermott, C.M., O'Connor, G.C., Managing radical innovation: an overview of emergent strategy issues. Journal of Product Innovation Management 19 (2),424-438, 2002.

[14] Pedersen, C. R., \& Dalum, B. Incremental versus radical change -The case of the digital north Denmark program. International Schumpeter Society Conference, Italy. DRUID/IKE Group, Department of Business Studies, Aalborg University, 2004.

[15] Schumpeter J. A History of Economic Analysis. London: Routledge. (Original publication in 1954.) 1994.

[16] Report of Global Innovation Index, , "Effective innovation policies for development." Available at:

https://www.globalinnovationindex.org/content/pag e/GII-Home [Accessed 12 January 2016], 2015.

[17] Vietnam 2035 Report, , Đổi mới sáng tạo đóng góp như thế nào vào phát triển bền vững của Việt Nam trong 20 năm tới? Available at:

http://dsi.mpi.gov.vn/vietnam2035/thao_luan_theo_ chu_de/5.html [Accessed 12 January 2016], (2015)

[18] Kanter, R.M. The Change Masters: Innovation for Productivity in the American Corporation. New York: Simon \& Schuster.1983.

[19] Amabile, T. M. From Individual Creativity to Organizational Innovation. In Innovation: A Cross-disciplinary Perspective, edited by $\mathrm{K}$. Gronhaug and G. Kaufmann. Oslo, Norway: Norwegian University Press. 1988.

(Or Amabile, T. M. (1988). A model of creativity and innovation in organizations. Research in Organizational Behavior, Vol 10, 123-167.

[20] Business Council of Australia (BCA), Managing the Innovating Enterprise. Melbourne, BCA, 1993.

[21] Phung X.N, Đổi mới sáng tạo của các doanh nghiệp Việt Nam. Tạp chí Khoa học ĐHQGHN, Kinh tế và Kinh doanh, 2013.
[22] Saunila, M., Pekkola, S, and Juhani Ukko . The relationship between innovation capability and performance: The moderating effect of measurement. International Journal of Productivity and Performance Management, Vol. 63 Iss: 2, $234-249,2014$.

[23] Betrand D. , Open Innovation in Software Means Open Source Software. OSS Watch, Oxford Dec.12th, 2009.

[24] Nassimbeni G., Technology, innovation capacity, and the export attitude of small manufacturing firms: a logit/tobit model. Research Policy, 30, 245-262, 2001

[25] Forsman H. Innovation capacity and innovation development in small enterprises. A comparison between the manufacturing and service sectors. Research Policy, 40, 739-750, 2011

[26] Vuong Quan Hoang, Nancy K. Napier, and Donaldine E. Samson "Relationship between Innovations, Capital Expenditures and Post-M\&A Performance: Evidence from Vietnam, 20052012," The IUP Journal of Business Strategy. Volume XI, Number 1, pages 34-41, (2014).

[27] Teece D. J.; Pisano G.; Shuen A Dynamic Capabilities and Strategic Management. Strategic Management Journal, Vol. 18, No. 7. (Aug., 1997), pp. 509-533, 1997

[28] Glaister, K.W., Buckley, P.J., Strategic motives for international alliance formation. Journal of Management Studies, 33 (3), 301-332, 1996.

[29] Elmquist, M., Le Masson, P., The value of a 'failed' R\&D project: an emerging evaluation framework for building innovative capabilities. R\&D Management 39 (2), 136-152, 2009.

[30] Mithas S., Ramasubbu N., Sambamurthy , How information management capability influences firm performance, 2011.

[31] Narver JC \& Slater SF., The effect of a market orientation on business profitability. Journal of Marketing, 20-34, 1990.

[32] Song X.M., Parry M.E., , What separates Japanese new product winners from losers, Journal of Product Innovation Management, 13, 422-439, (1997)

[33] Gatignon, H., Xuereb, J.M., . Strategic orientation of the performance. Journal of Marketing Research, 34 (1), 77-79.(1997) 
[34] Hurley, R. and Hult, T. Innovation, market orientation and organizational learning: an integration and empirical examination. Journal of Marketing, Vol. 62, July, pp. 42-54, 1998.

[35] Han, J.K., Kim, N., Srivastava, R., . Market orientation and organizational performance: Is innovation a missing link? Journal of Marketing, 62 (4), 30-45, 1998.

[36] Venkatraman, N., \& Ramanujam, V., Measurement of business performance in strategy research: a comparison of approaches. Academy of Management Review. 1(4), 801-814, (1986).

[37] Lonnquivist A., Measurement of Intangible Success Factors: Case study on the Design, Implementation and Use of Measures. Tampere. (2004).

[38] Tangen S., Demystifying productivity and performance. International Journal of Productivity and Performance Management, Vol. 54 Iss: 1, pp.34 - 46, 2005.

[39] Feurer, R. and Chaharbaghi, K. . Defining Competitiveness: A Holistic Approach. Management Decision, 32(2): 49-58, (1994).

[40] Buckley, P.J., Pass, C.L and Prescott, K. , Measures of International Competitiveness: A Critical Survey. Journal of Marketing Management, 4(2): 175-200, (1988)

[41] Covin and Slevin, 1991 Covin, J. G. and D. P. Slevin A conceptual model of entrepreneurship as firm behavior. Entrepreneurship Theory and Practice, Fall, pp. 7-25 (1991).

[42] Kravis, I.B., and Lipsey, R.E. Sources of Competitiveness of the United States and of its Multinational Firms. Review of Economics and Statistics, Vol. 74, pp. 193-201.(1992).

[43] Kaplan, R. S. and D.P. Norton, The Balanced Scorecard: Translating Strategy into Action. Boston: HBS Press (1996).

[44] Cheng $\mathrm{Wu}$ et al, The Effects of Corporate Governance on Firm Performance, 2001.

[45] Ketokivi, M. A. \& Schroeder, R. G. Strategic, structural contingency and institutional explanations in the adoption of innovative manufacturing practices. Journal of Operations Management, Vol. 22, No. 1, pp. 63-89.(2004).

[46] Calantone, R. J., S. T. Cavusgil and Z. Yushan. Learning orientation, firm innovation capability, and firm performance. Industrial Marketing Management, 31(6), 515-524, (2002).

[47] Cainelli, G., Evangelista, R. and Savona, M. The impact of innovation on economic performance in services. Service Industries Journal, Vol. 24 No. 1, pp. 116-130, (2004)

[48] Cho, H.-J. and Pucik, V. Relationship between innovativeness, quality, growth, profitability, and market value", Strategic Management Journal, Vol. 26 No. 6, pp. 555-75. (2005).

[49] Armbruster, H., Bikfalvi, A., Kinkel, S. and Lay, G. Organizational innovation: the challenge of measuring non-technical innovation in large-scale surveys. Technovation, Vol. 28 No. 10, pp. 64457, (2008)

[50] Garcia - Morales, V. J., Lloréns-Montes, F. J., \& Verdú-Jover, A. J. Influence of personal mastery on organizational performance through organizational learning and innovation in large firms and SMEs.Technovation, 27(9), 547-568, (2007).

[51] Rosenbusch, N., Unger, J.M., Rauch, A., Frese, M. , Human capital and entrepreneurial success: A meta-analytical review. Journal of Business Venturing, Volume 26, Issue 3, May 2011, Pages 341-358, (2009)

[52] Tsai, M. C., Lee, W., \& Wu, H. C. Determinants of RFID adoption intention: Evidence from Taiwanese retail chains. Information \& Management, 47(5), 255-261, (2010).

[53] Dadfar, H., Dahlgaard, J. J., Brege, S., \& Alamirhoor, A. Linkage between organisational innovation capability, product platform development and performance: The case of pharmaceutical small and medium enterprises in Iran. Total Quality Management \& Business Excellence, 24(7-8), 819-834.(2013).

[54] Vuong Quan Hoang, Nancy K. Napier, Vu Kim Hanh, Nguyen Manh Cuong, and Tran Tri Dung., (2014) Measuring Corporate Innovation Capacity: Experience and Implications from i2Metrix Implementation in Vietnam. ASEAN Journal of Management and Innovation (January - May, 2014, Vol. 1, No. 1, pp. 1-17. DOI: 10.14456/ajmi.2014.5[ISSN: 2351-0110]

[55] Chow C. W. and Wim A. Van Der Stede, The Use and Usefulness of Nonfinancial Performance 
Measures, Management Accounting Quarterly, (2006).

[56] Bapuji H., Loree D., Crossan M. Connecting external knowledge usage and firm performance: An empirical analysis. Journal of Engineering and Technology Management, 28, 215-231.(2011).

[57] Hindle K., Small-i or Big-i? How entrepreneurial capacity transforms "small-I" into "BIG-I" innovation: Some implications for national policy. Telecommunications Journal of Australia, 52(3): 51-63, 2002.

[58] Wilkinson, Andrew, Hindle, and Kevin (2006), Defining, measuring and assessing entrepreneurial capacity: a review of selected literatures.

[59] Powell To Patent or Not: Faculty Decisions and Institutional Success at Technology Transfer. Journal of Technology Transfer 26(1):99-114 (January 2001), Jason Owen-Smith, W.W. Powell, (2001)

[60] Erik Strøjer \& Smith, Valdemar, . Commercialization of Innovations and Firm Performance. University of Aarhus, Aarhus School of Business, Department of Economics. Working Papers 08-26.(2008)

[61] Bayus B.L., Erickson G,M , Jacobson R. The Financial Rewards of New Product Introductions in the Personal Computer Industry. Article in Management Science, 49(2):197-210, (2003).

[62] Damanpour, F. and Evan, W. M. Organizational innovation and performance: The problem of organizational lag. Administrative Science Quarterly, 29: 392-409, (1984).

[63] Mzoughi, N., Bahri, N., \& Ghachem, M. S. Impact of Supply Chain Management and ERP on Organizational Performance and Competitive Advantages: Case of Tunisian Companies. Journal of Global Information Technology Management, 11(3), 24.(2008).

[64] Kaplan, R.S., and Norton, D. P., The Balanced Scorecard Measures That Drive Performance. Harvard Business Review.(1992).

[65] Arroyo, P., \& Pozzebon, M. Implementing a Three-Level Balanced Scorecard System at Chilquinta Energía. International Journal of Case Studies in Management, 8(2), 1-20.(2010).

[66] Chaston, I, \& Scott, GJ. Entrepreneurship and open innovation in an emerging economy. Management Decision, 50(7), 1161-1177(2012).
[67] ZábojníkJ. Subjective evaluations with performance feedback, The RAND Journal of Economics, Volume 45, Issue 2, pages 341369,(2014)

[68] Song, M., Droge, C., Hanvanich, S. \& Calantone, R. Marketing and technology resource complementarily: An analysis of their interaction effect in two environmental contexts. Strategic Management Journal, 26(3): 259-276.(2005).

[69] Werts, C. E., Linn, R. L., \&Jöreskog, K. G., Interclass reliability estimates: Testing structural assumptions. Educational and Psychological Measurement, 34, pp25-33. (1974)

[70] Churchill, G.A., Jr., A Paradigm for Developing Better Measures of Marketing Constructs. Journal of Marketing Research, XVI (February), 64-73, (1979).

[71] Nunnally, J.C., and Bernstein, I.H., Psychometric Theory, (3rd ed.) McGraw-Hill, New York, (1994).

[72] Götz O, Liehr-Gobbers K, Krafft M., Evaluation of structural equation models using the partial least squares (PLS) approach. In Handbook of Partial Least Squares: Concepts, Methods and Applications, Vinzi VE, Chin WW, Heneseler J, Wang H. (eds). Springer: Berlin (2009).

[73] Anna B. Costello and Jason W. Osborne, Best Practices in Exploratory Factor Analysis: Four Recommendations for Getting the Most From Your Analysis. Practical Assessment Research \& Evaluation, Vol 10, No 7, North Carolina State University (2005).

[74] Rietveld, T. and Van Hout, R., Statistical Techniques for the Study of Language and Language Behavior. Berlin - New York: Mouton de Gruyter (1993)

[75] Habing, B., Exploratory Factor Analysis. Website: (2003).

http://www.stat.sc.edu/ habing/courses/530EFA.pd f (Accessed 10 May 2004)

[76] Field, A., Discovering Statistics using SPSS for Windows. London - Thousand Oaks - New Delhi: Sage publications.(2000).

[77] Hair, J.F.Jr., Anderson, R.E., Tatham, R.L., \& Black, W.C., Multivariate Data Analysis. Upper Saddle River, 5th Edition, (1998).

[78] John T.Pohlmann and Dennis W. Leitner, A Comparison of Ordinary Least Squares and 


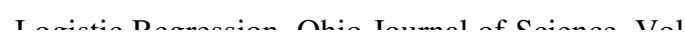

[79] Grant, R. M. Toward a knowledge-based theory of the firm. Strategic management journal, 17(S2), 109-122, (1996).

[80] Prusak, L. Where did knowledge management come from?. IBM systems journal, 40(4), 1002, (2001).

[81] Gold, A. H., \& Arvind Malhotra, A. H. S. Knowledge management: An organizational capabilities perspective. Journal of management information systems, 18(1), 185-214, (2001).

[82] Zahra, S. A., \& Covin, J. G. Contextual influences on the corporate entrepreneurship-performance relationship: A longitudinal analysis. Journal of business venturing, 10(1), 43-58, (1995).

[83] Shane, S., \& Venkataraman, S. The promise of entrepreneurship as a field of research. Academy of management review, 25(1), 217-226, (2000).

[84] Lumpkin, G. T., \& Dess, G. G. Clarifying the entrepreneurial orientation construct and linking it to performance. Academy of management Review,21(1), 135-172, (1996).

[85] Lukianchuk, G. Te impact of enterprise risk management on firm performance of small and medium enterprises.European Scientific Journal, 11(13), (2015).

[86] Pagach, D., \& Warr, R. The characteristics of firms that hire chief risk officers. Journal of Risk and Insurance, 78(1), 185-211, (2011).
[87] Walter, S. D. The partial area under the summary ROC curve. Statistics in medicine, 24(13), 20252040, (2005).

[88] Human, G., \& Naudé, P. Exploring the relationship between network competence, network capability and firm performance: A resource-based perspective in an emerging economy. Management Dynamics, 18(1), 2, (2009).

[89] Protogerou, a., Caloghirou, Y., \& Lioukas, S. Dynamic capabilities and their indirect impact on firm performance. Industrial and Corporate Change, 21(3), 615-647, (2011).

[90] Bower, J. L., and C. M. Christensen Customer Power, Strategic Investment, and the Failure of Leading Firms. Strategic Management Journal 17, no. 3 197-218, (1996).

[91] Narver J. C., Slater S. F. and MacLachlan D. L. Responsive and proactive market orientation and new product success, Journal of Product Innovation Management, Vol. 21, No. 5, pp. 334347, (2004).

[92] Morgan III, C.A., Hazlett, G. A., Doran, A., Garrett, S., Hoyt, G., Thomas, P., et al. Accuracy of eyewitness memory for persons encountered during exposure to highly intense stress. International Journal of Law and Psychiatry, 27, 265-279, (2004). .

\title{
Mối quan hệ giữa khả năng đổi mới và hiệu suất của doanh nghiệp đầu tư nước ngoài tại Việt Nam
}

\author{
Lê Thị Thu Hà, Phạm Thùy Linh, Hồ Thị Thu Quỳnh, Trần Thị Kim Chi \\ Đại học Ngoại thuoong, 91 Chùa Láng, Đống Đa, Hà Nội, Việt Nam
}

Tóm tắt: Tương tự như những nghiên cứu trước đó, nghiên cứu này khẳng định mối quan hệ tích cực giữa khả năng đổi mới và hiệu suất của công ty bằng cách đo lường và đánh giá các dữ liệu thực nghiệm từ 52 doanh nghiệp có vốn đầu tư nước ngoài tại Việt Nam (FIEs). Nghiên cứu này cung cấp một cái nhìn sâu sắc về các khía cạnh khác nhau của sự đổi mới trong doanh nghiệp nước ngoài như: 
các loại đổi mới, tần suất thực hiện đổi mới, phương pháp đầu tư đổi mới. Kết quả của phân tích dữ liệu sơ cấp theo phương pháp hồi quy tuyến tính (OLS) cho thấy sự khác biệt khá nhỏ giữa tác động của 7 nhóm năng lực lên hiệu suất của công ty mặc dù năng lực phát triển vẫn có ảnh hưởng lớn nhất với hệ số là 0,453 . Những phát hiện của nghiên cứu này một lần nữa nhấn mạnh rằng đổi mới và khả năng đổi mới của công ty chính là yếu tố quyết định hiệu suất hàng đầu.

Từ khóa: Doanh nghiệp có vốn đầu tư nước ngoài, đổi mới, khả năng đổi mới. 